\title{
Buku Ajar Bahasa Arab
}

\author{
Fardan Abdillah M
}

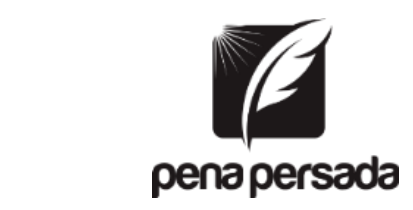

PENERBIT CV. PENA PERSADA 
Buku Ajar Bahasa Arab

Penulis:

Fardan Abdillah M

ISBN : 978-623-315-713-1

Design Cover :

Retnani Nur Briliant

Layout :

Eka Safitry

\section{Penerbit CV. Pena Persada}

\section{Redaksi :}

Jl. Gerilya No. 292 Purwokerto Selatan, Kab. Banyumas

Jawa Tengah

Email : penerbit.penapersada@gmail.com

Website : penapersada.com Phone : (0281) 7771388

\section{Anggota IKAPI}

All right reserved

Cetakan pertama : 2021

Hak Cipta dilindungi oleh undang-undang. Dilarang memperbanyak karya tulis ini dalam bentuk apapun tanpa izin penerbit 


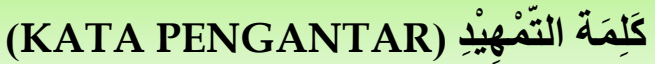

Alhamdulillah, rasa syukur penulis panjatkan kepada Allah swt. atas curahan rahmat dan karunia ilmu-Nya yang tidak terbatas dan salawat serta salam kepada nabi Muhammad saw., sehingga penulis dapat menyelesaikan Buku Ajar Bahasa Arab.

Kesadaran umat islam akan pentingnya mempelajari bahasa Arab semakin tinggi, selain telah berfungsi sebagai bahasa ilmu pengetahuan dan komunikasi juga berfungsi sebagai bahasa agama. Oleh sebab itu, proses pembelajaran bahasa Arab senantiasa diberikan motivasi belajar sebagai sarana dalam menunjang pembelajaran agama maupun umum, maka diharapkan mahasiswa dan mahasiswi dapat berkomunikasi serta memahami bacaan-bacaan dalam bahasa Arab secara sederaha. Hal ini sangat membantu pemahaman siswa dalam mempelajari dua sumber utama ajaran agama Islam yang berbahasa Arab yaitu al-Qur'an dan Hadis.

Buku ajar ini disusun secara sederhana dan praktis sehingga menjadi sarana pembelajaran bahasa Arab di IAIN Sorong, yang membutuhkan sebuah buku ajar yang sesuai dengan karakter mahasiswa dan mahasiswi, maka memunculkan ide baru dalam menyusun materi ajar bahasa Arab bagi Institut Agama Islam Negeri (IAIN) Sorong, sehingga dapat memudahkan mahasiswa dalam mempelajari bahasa Arab.

Penulis berharap, buku ajar ini dapat menjadi sarana pembelajaran yang lebih efektif dan efisien sehingga dapat meningkatkan minat belajar mahasiswa dalam pelajaran bahasa Arab. Saran dan kritik yang membangun dari semua pihak sangat kami harapkan.

Sorong, 28 Mei 2021

Rektor

Hamzah 


\section{إرْتشَادُ إِنْتِعْمَال المَادَّة \\ (Petunjuk Penggunaan Materi)}

- Buku ajar ini digunakan untuk semua bab mata pelajaran bahasa Arab bagi mahasiswa IAIN Sorong

- Tema pembelajaran dalam setiap bab ditulis dengan ukuran huruf tebal
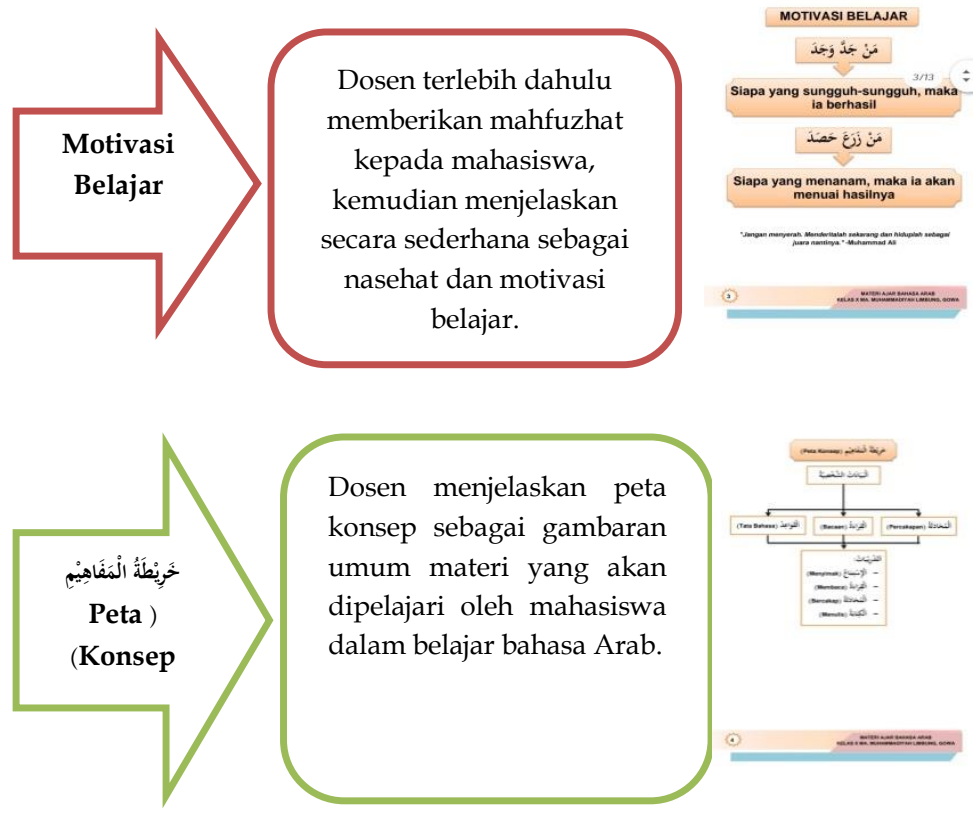

Dosen menjelaskan peta konsep sebagai gambaran umum materi yang akan dipelajari oleh mahasiswa dalam belajar bahasa Arab.
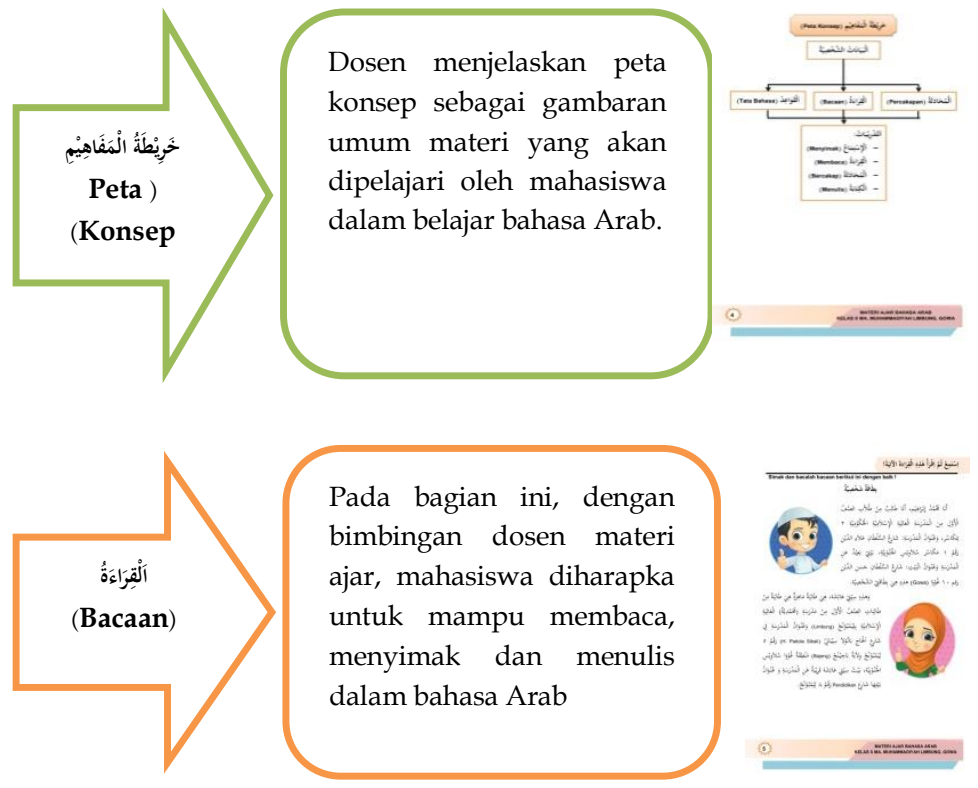


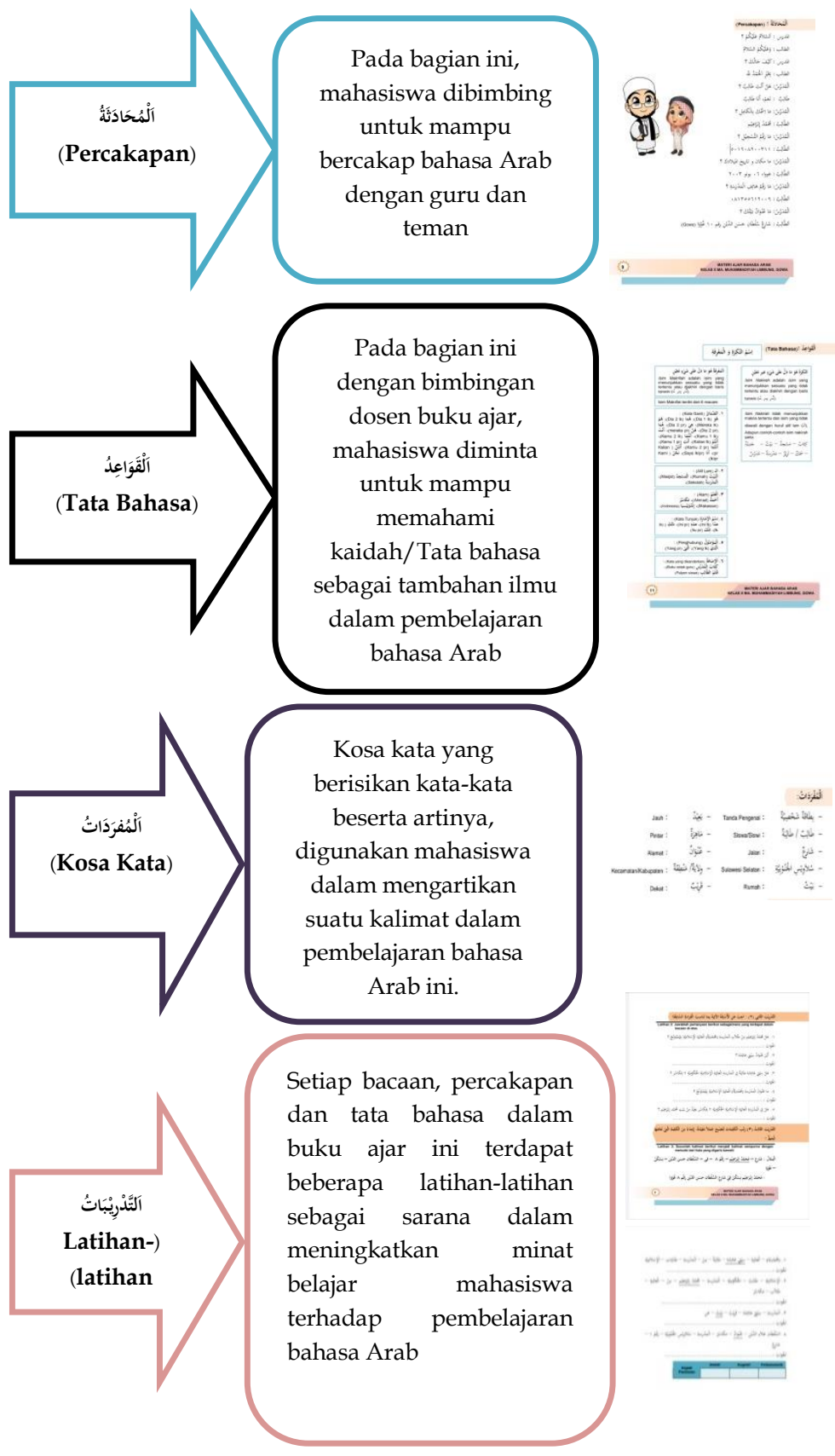




\section{(آَفَهْرَسن (Daftar Isi)}

$$
\text { iii }
$$
كَلِمَةُ النَّْْهِيْدِ (KATA PENGANTAR)

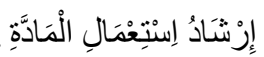

iv .(Petunjuk Penggunaan Materi)

iv. آلَفَهْرَسُ (Daftar Isi)

vi.

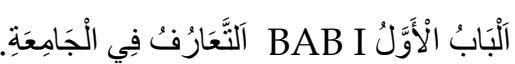

ir

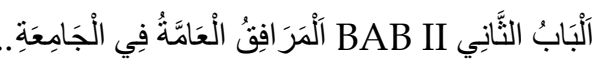

r纟

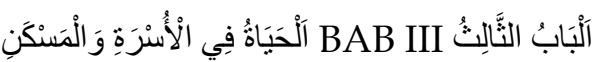
rᄉ

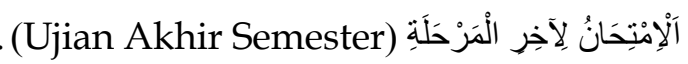

«

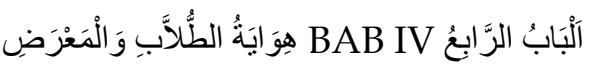
o

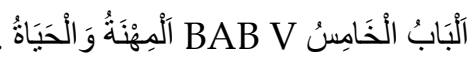
TV آلَبَابُ السَّادِسُ BAB VI نِظَامُ الْجَامِعَة. . 4

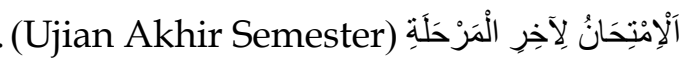
71 ألَمَرَاجِعُ (DAFTAR PUSTAKA). 41 (ألَمَسْرَدُ 
BAB

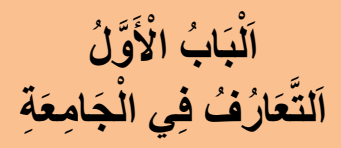

PESAN MORIL DAN MOTIVASI BELAJAR

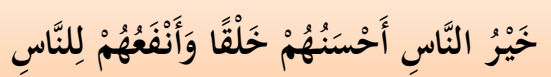

Sebaik-baik manusia itu adalah yang paling baik budi pekertinya dan yang paling bermanfaat bagi manusia.

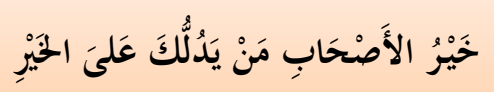

Sebaik-baik teman itu ialah yang menunjukkan kamu kepada kebaikan.

"Carilah teman untuk menenangkan hati dan pikiran, maka perhatikanlah baik-baik tentang keselamatanmu dan kesejahteraannya." - Abu Hamid Al Ghazali 


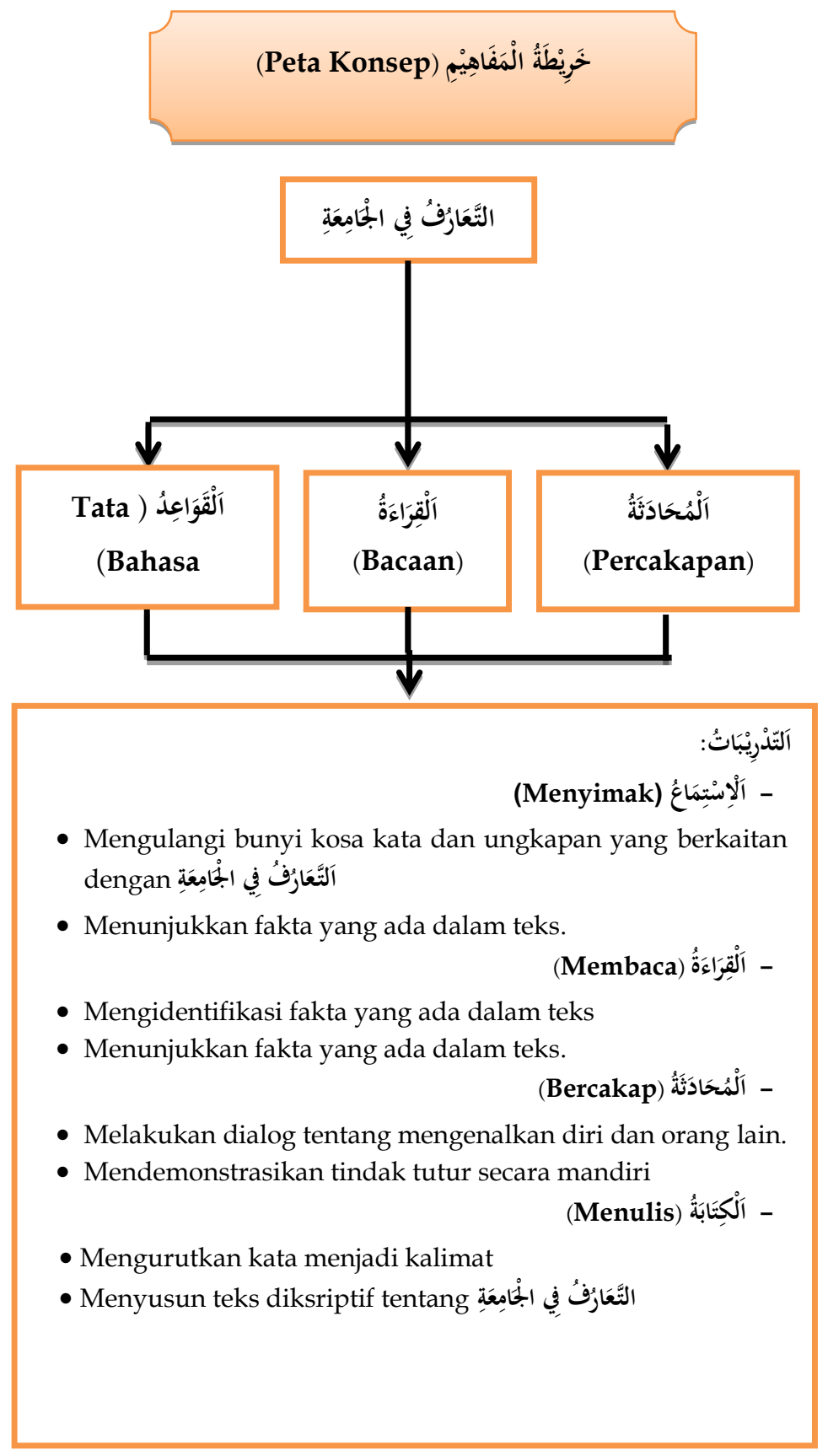




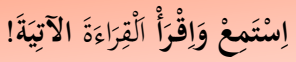

\section{Simak dan bacalah bacaan berikut ini dengan baik !}

اكَتْعَارُفُ بَيْنَ إِبْرَاهِيْمِ وَعَائُشَّة

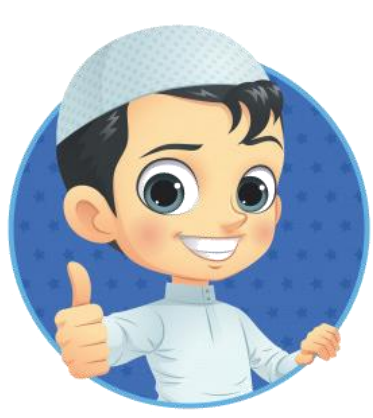

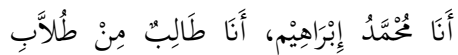

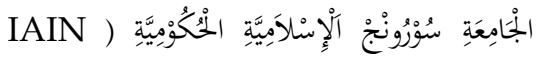

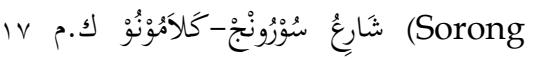

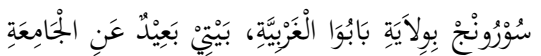

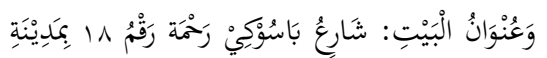

سُوْرُونْجْ.

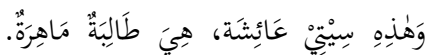

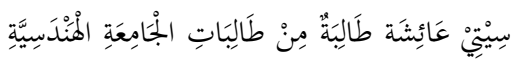

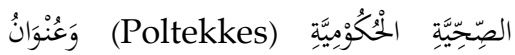

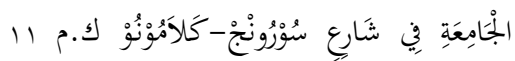

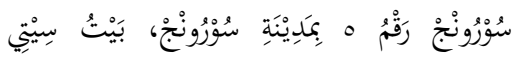

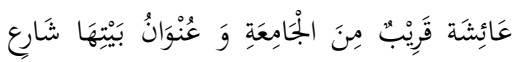

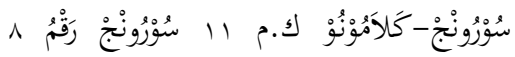
بِمَدِينَةِة سُوْرُونْجْ.

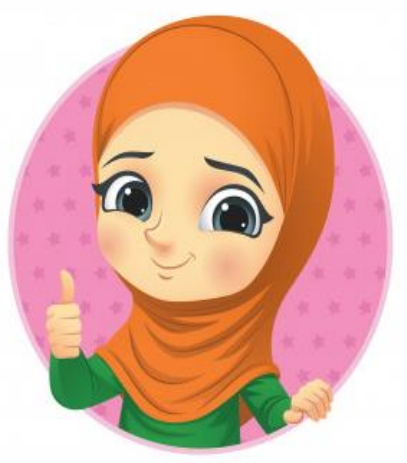

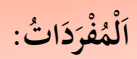

\begin{tabular}{|c|c|c|c|c|}
\hline Jauh : & بَعِيْدُ & - & Perkenalan : & آكَّتَعارُفنُ \\
\hline Pintar : & مَاهِرَةُ & - & Mahasiswa/i : & طَالِبٌْ / طَالِلِةٌ \\
\hline Alamat : & ع عُنْوَانْ & - & Jalan : & شَارِعُ \\
\hline Provinsi & و ولاَيَةُّ & - & Papua Barat : & بَابُبًَا الْغَرَبَيَّةُ \\
\hline abupaten & مَنْطِقَةُّة & - & Rumah : & \\
\hline
\end{tabular}

Dekat : - 


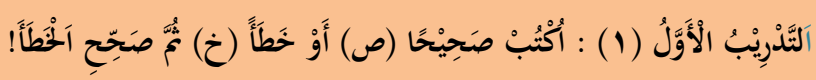

Latihan 1: Tulislah uraian benar atau salah kemudian benarkan kalimat yang tidak sesuai dengan bacaan

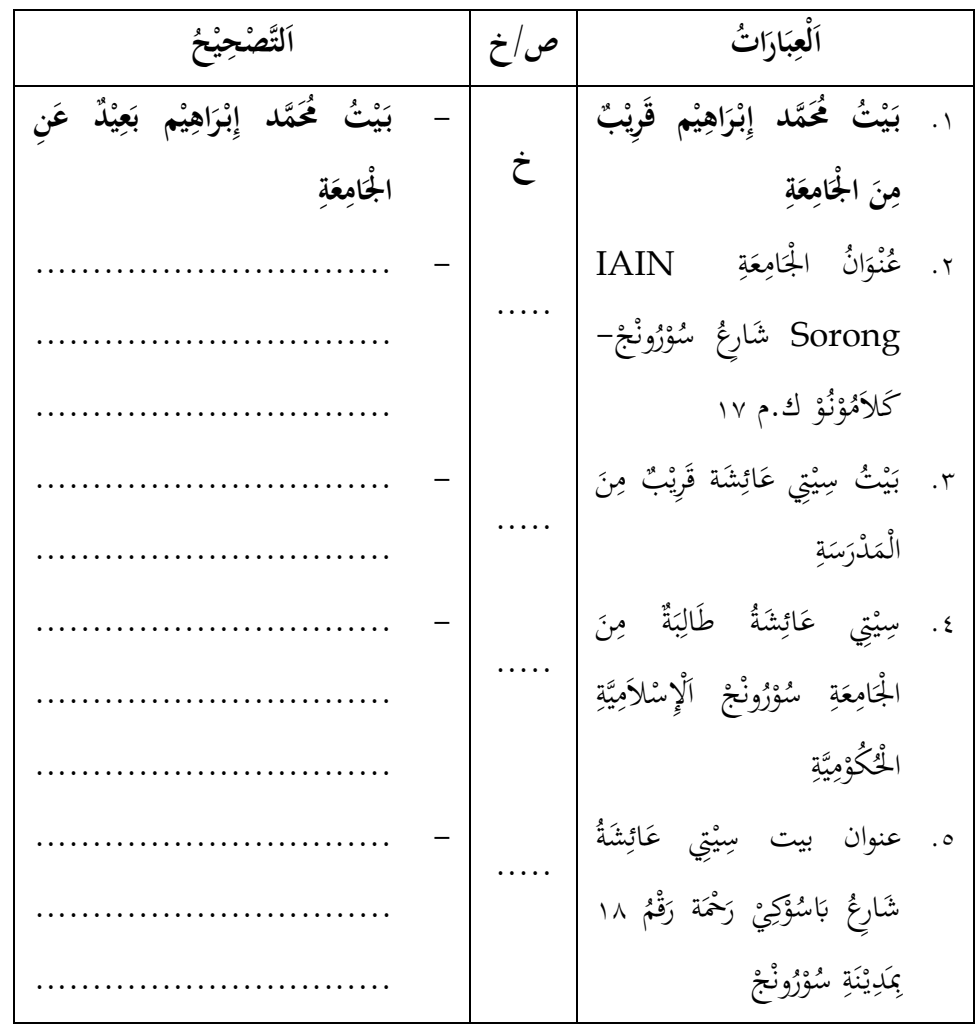




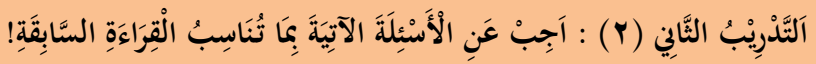

Latihan 2: Jawablah pertanyaan berikut sebagaimana yang terdapat dalam bacaan di atas

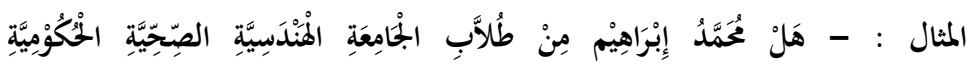

९(Poltekkes)

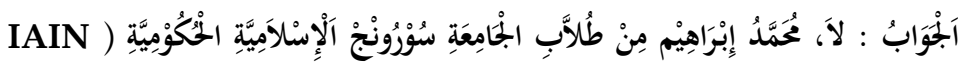

(Sorong

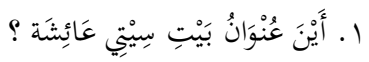

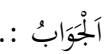

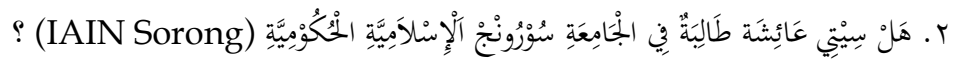
اَلَجَوَابُ :

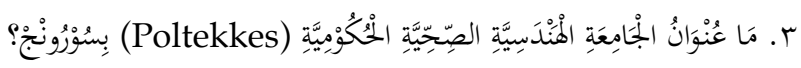
اَلَجْوَابُ :

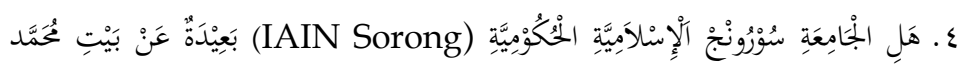

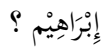

اَبَجْوَابُ :. 


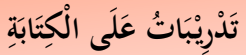

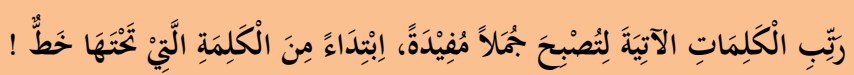

Susunlah kalimat berikut menjadi kalimat sempurna dengan memulai dari kata yang digaris bawahi

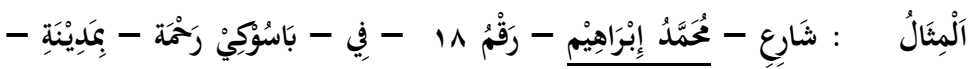

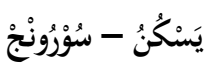

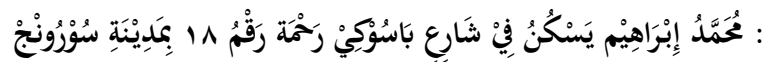

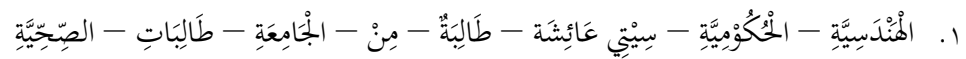
: آَجْوَابُ

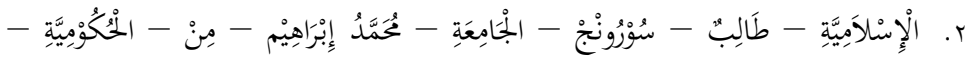
طُلأَبِ آنَجْوَابُ :

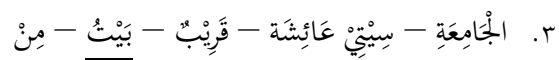
: آَجْوَابُ

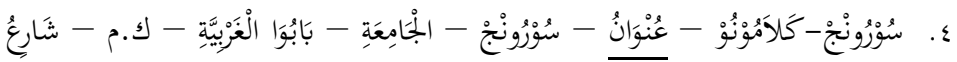
سُوْرونْجْ

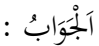

\begin{tabular}{|l|l|c|}
\hline Paraf Dosen & Nilai & $\begin{array}{c}\text { Tanggal } \\
\text { Penilaian }\end{array}$ \\
\hline & & \\
\hline
\end{tabular}




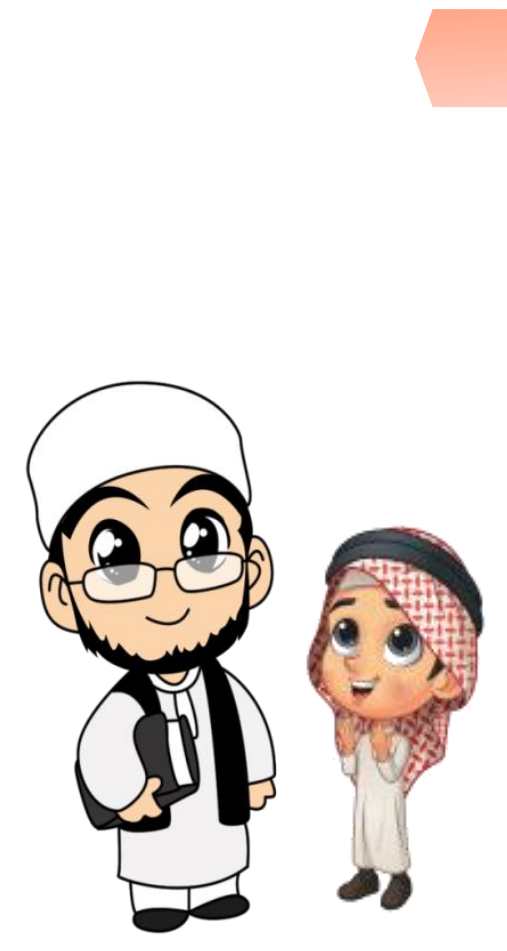

(الَلْحَحَادَتَةُة ! (Percakapan

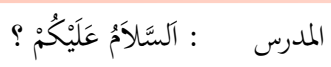

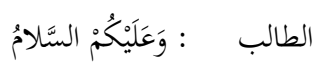

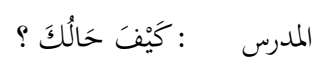

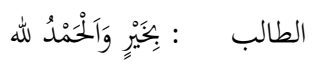

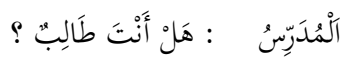

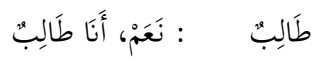

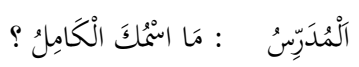

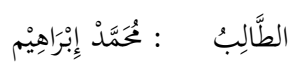

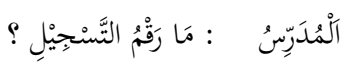

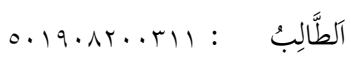

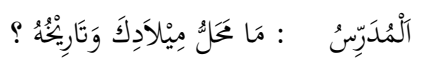

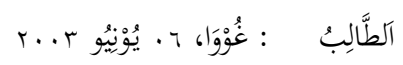

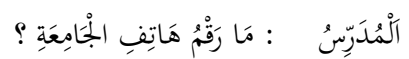

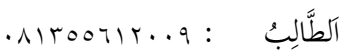

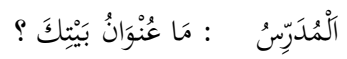

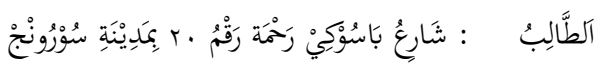




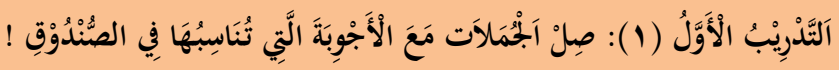

Latihan 1: Pasangkanlah kalimat berikut dengan jawaban sesuai di dalam kotak

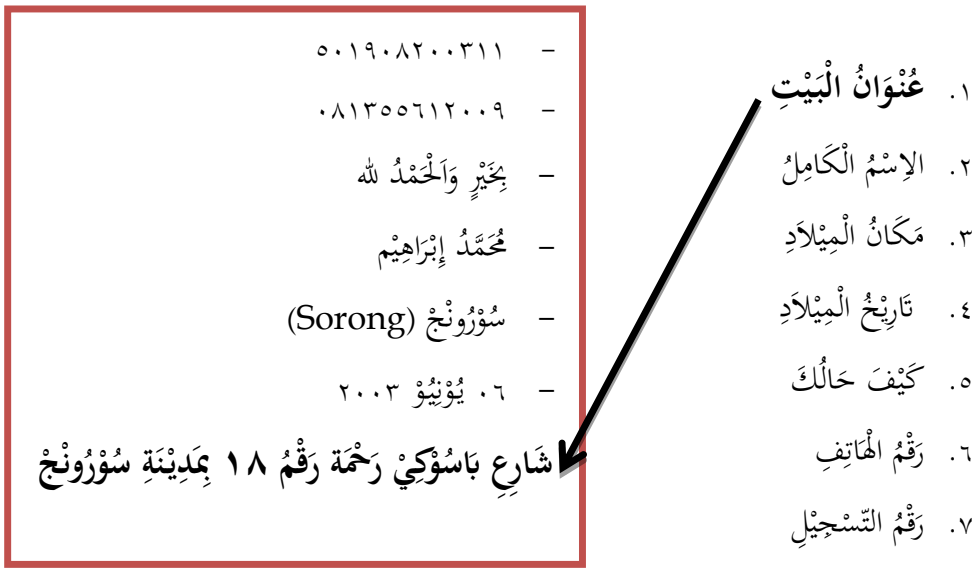

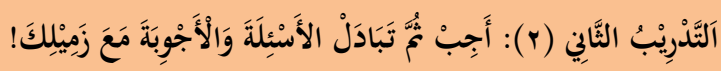
Latihan 2: Carilah pasangan masing-masing untuk mempraktikkan percakapan berikut!

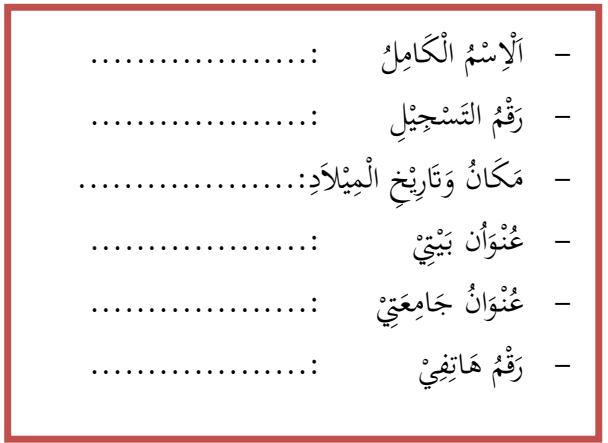

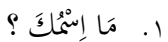

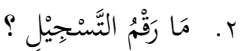

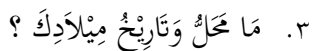

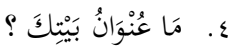

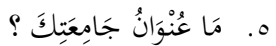

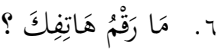

\begin{tabular}{|l|l|l|}
\hline Paraf Dosen & Nilai & Tanggal Penilaian \\
\hline & & \\
\hline
\end{tabular}


(ألْقَوَاعِدُ ! Tata Bahasa) إسنمُ النَّكرَِِة وَالْمَعْفَفَة

\section{ألْمَعْفَةُ هُوَ مَا دَلَّ عَلَى شَيْيَ مُعَيَّن}

Isim Makrifah adalah isim yang sudah diketahui maknanya atau bersifat khusus dengan memperhatikan keteantuannya.

Isim Makrifat terdiri dari 6
ketentuan:

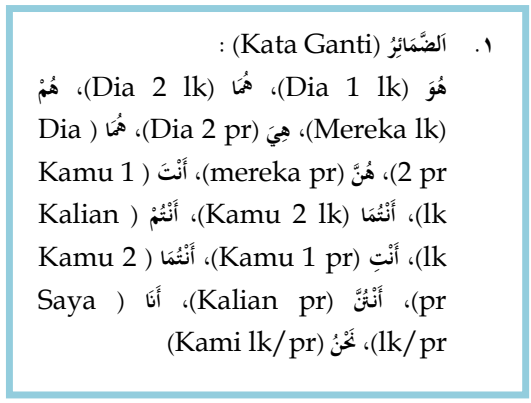
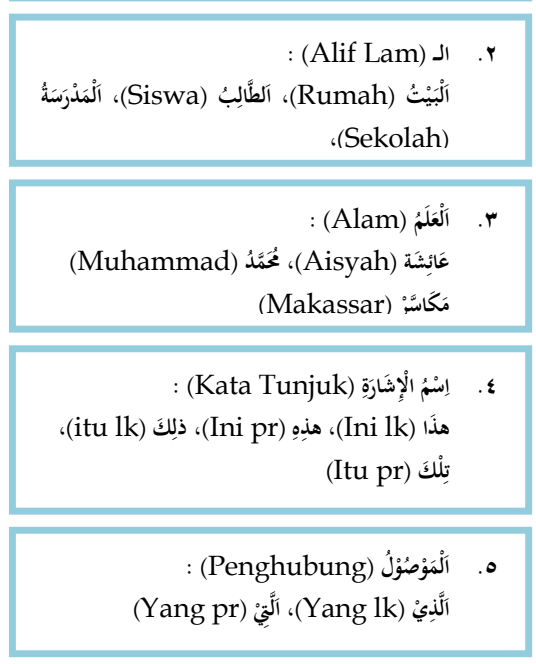

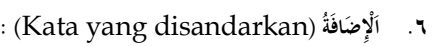

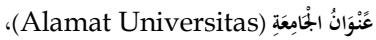

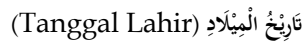

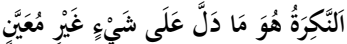

Isim Nakirah adalah isim yang menunjukkan sesuatu yang tidak tertentu atau diakhiri dengan baris tanwin $(\dot{*},-,-, *)$.

\section{Isim Nakirah tidak} menunjukkan makna tertentu dan isim yang tidak diawali dengan huruf alif lam (J) atau masih bersifat umum, Adapun contoh-contoh isim nakirah yaitu:

هَاتِفْ (Telepon) - عُنْوَانُ (Alamat)

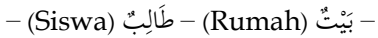

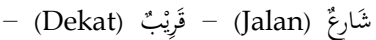
جَامِعَةُ (Universitas) - بَعِيْدُ (Uauh) 


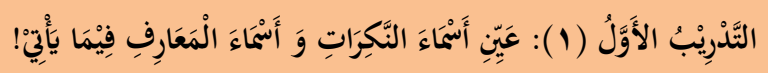

Latihan 1: Tentukanlah kalimat berikut yang termasuk isim nakirah dan isim ma'rifah

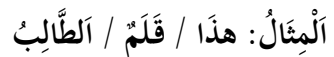

\begin{tabular}{|c|c|c|}
\hline 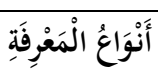 & 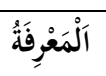 & آلَلْكِكَةُة \\
\hline إِسْمُ اللإلْشَارَة & هذًا & \\
\hline آَلْ & آلطَّألِبِ & قلم \\
\hline
\end{tabular}

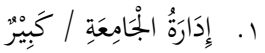

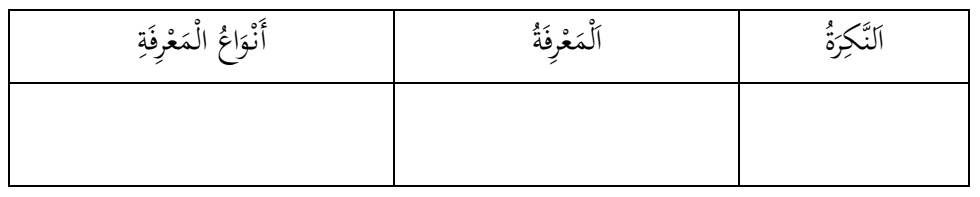

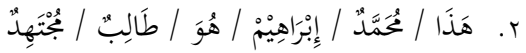

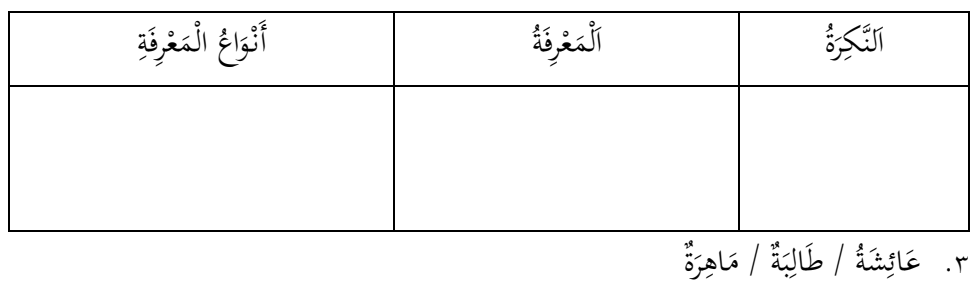

\begin{tabular}{|c|c|c|}
\hline أَنْوَاعُعُ الْمَعْرَفَفة & آلَمْعَرْفرةُ & اكلنّكَركةُ \\
\hline & & \\
\hline
\end{tabular}

\begin{tabular}{|l|l|l|}
\hline \multicolumn{1}{|c|}{} & \multicolumn{1}{|c|}{$|c|$} \\
\hline & & \\
\hline & & \\
\hline
\end{tabular}




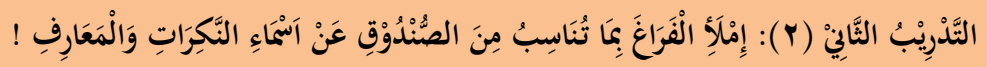

Latihan 2: Isilah titik-titik berikut yang sesuai jawabannya di dalam kotak dengan memperhatikan isim nakirah dan isim ma'rifah
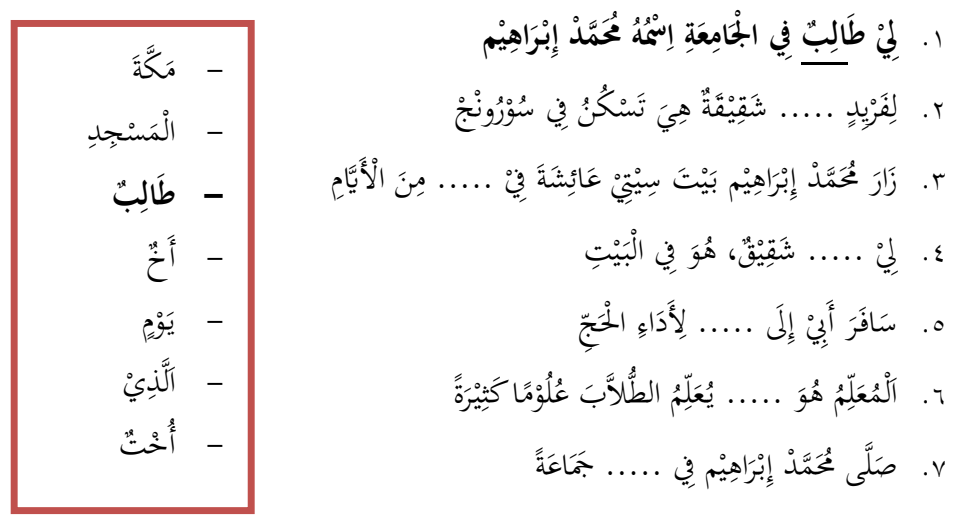

\begin{tabular}{|l|l|l|}
\hline Paraf Dosen & Nilai & Tanggal Penilaian \\
\hline & & \\
\hline
\end{tabular}




\section{BAB}

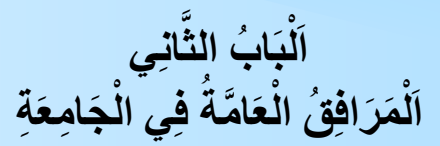

PESAN MORIL DAN MOTIVASI BELAJAR

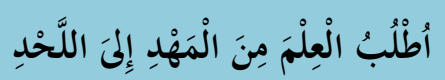

Tuntutlah ilmu sejak dari buaian hingga liang kubur.

\section{خَيْرُ مَالِلكَ مَا نَفَعَكَ}

Sebaik-baik hartamu adalah yang bermanfaat bagimu.

"Jangan pernah berhenti belajar, karena hidup tak pernah berhenti mengajarkan." -Anonim 

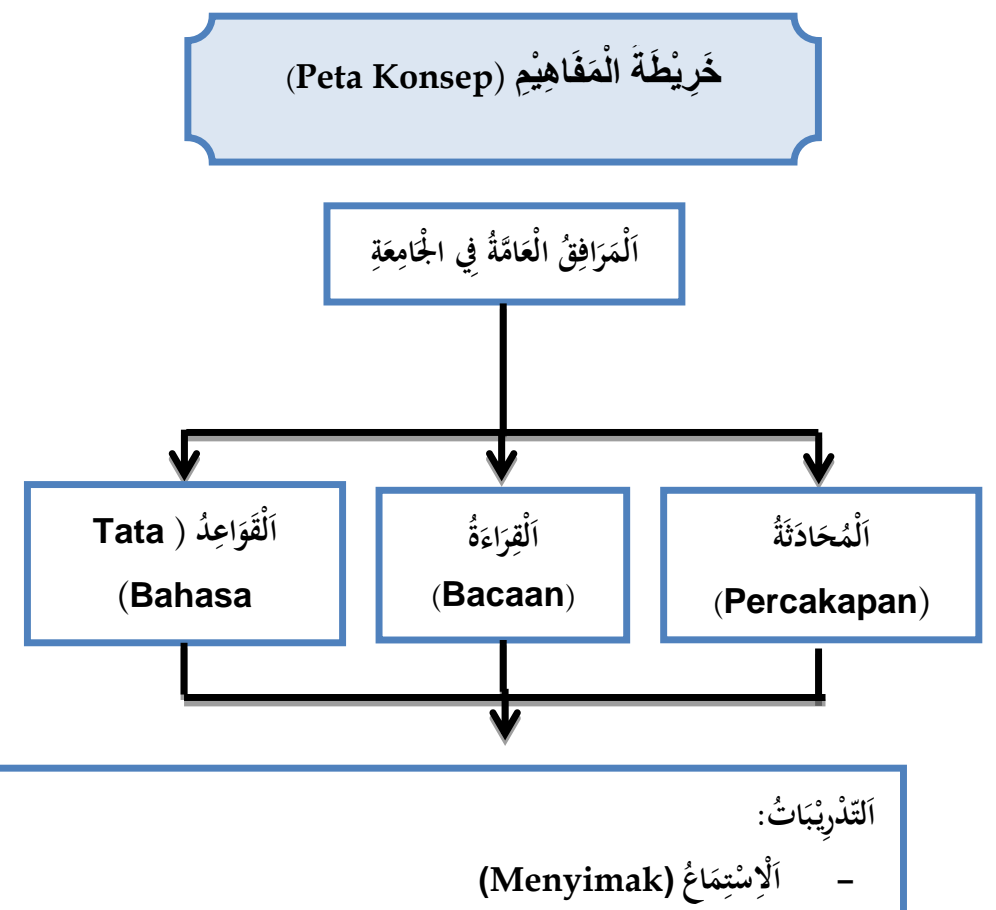

- Mengulangi bunyi kosa kata dan ungkapan yang

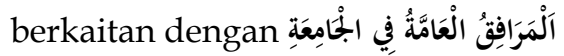

- Menunjukkan fakta yang ada dalam teks.

(Membaca) -

- Mengidentifikasi fakta yang ada dalam teks

- Menunjukkan fakta yang ada dalam teks.

(Bercakap) -

- Melakukan dialog yang ada dalam teks.

- Mendemonstrasikan tindak tutur secara mandiri

(Menulis) -

- Mengurutkan kata menjadi kalimat

- Menyusun teks deskriptif tentang الْمَرَافِقُُ الْعَامَّةُ فِي الجَحَامِعَةِ 


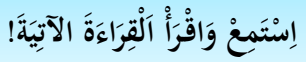

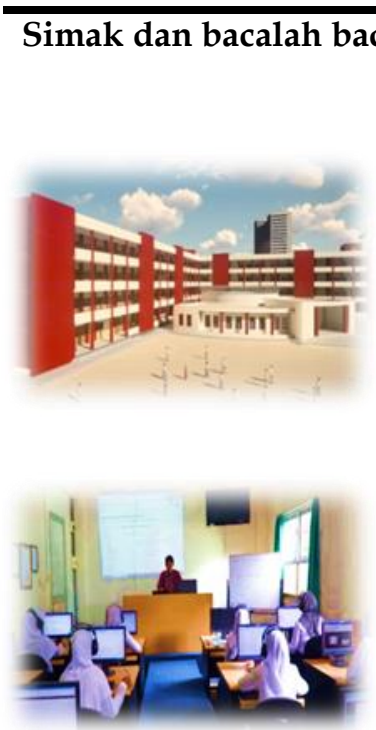

ألْمَرَافِقٌُ الْعَامَّةُ

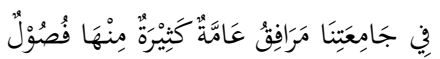

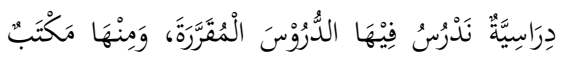

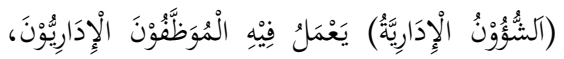

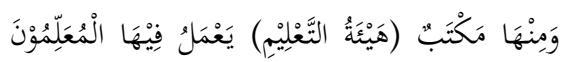

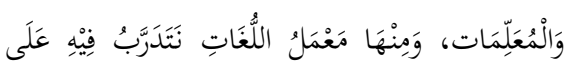

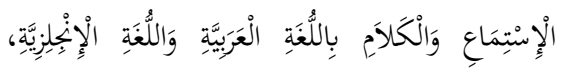

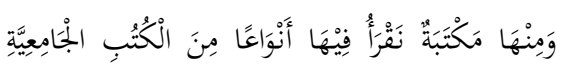

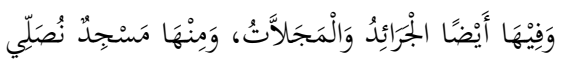

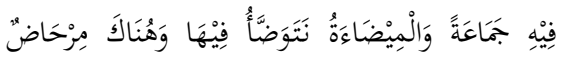

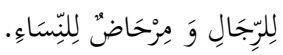

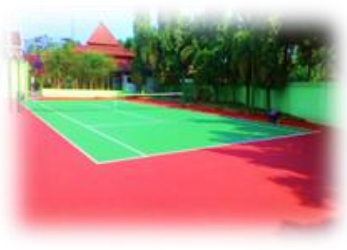

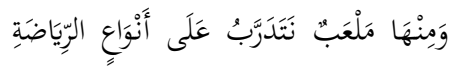

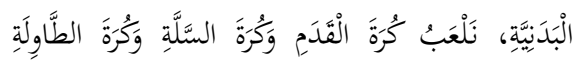

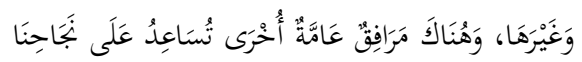

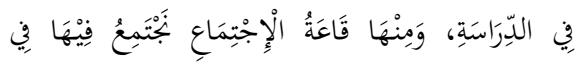

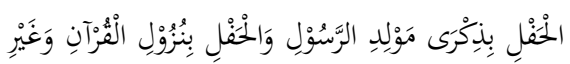

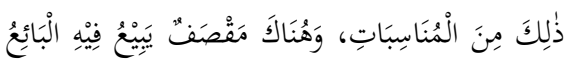

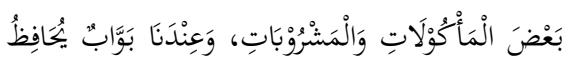

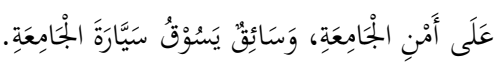

